Key Words:

Cesium

Tetraphenylborate

Retention: Permanent

\title{
ANALYSIS OF THE LEACHING EFFICIENCY OF INHIBITED WATER AND TANK 23H SIMULANT IN REMOVING RESIDUES ON TANK 48H WALLS
}

F. F. Fondeur

T. L. White

L. N. Oji

C. J. Martino

W. R. Wilmarth

July 31, 2006

Westinghouse Savannah River Company

Savannah River Site

Aiken, SC 29808

Prepared for the U. S. Department of Energy Under

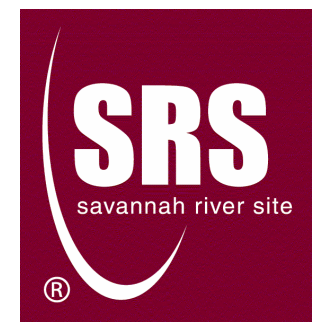

Contract Number DE-AC09-96SR18500 


\section{DISCLAIMER}

This report was prepared by Westinghouse Savannah River Company (WSRC) for the United States Department of Energy under Contract No. DE-AC09-96SR18500 and is an account of work performed under that contract. Neither the United States Department of Energy, nor WSRC, nor any of their employees makes any warranty, expressed or implied, or assumes any legal liability or responsibility for the accuracy, completeness, or usefulness, of any information, apparatus, or product or process disclosed herein or represents that its use will not infringe privately owned rights. Reference herein to any specific commercial product, process, or service by trademark, name, manufacturer or otherwise does not necessarily constitute or imply endorsement, recommendation, or favoring of same by WSRC or by the United States Government or any agency thereof. The views and opinions of the authors expressed herein do not necessarily state or reflect those of the United States Government or any agency thereof.

\section{Printed in the United States of America \\ Prepared For \\ U.S. Department of Energy}




\section{AUTHORS}

\section{REVIEWS AND APPROVALS}

F. F. Fondeur, author, Chemical Science and Technology 7.06

T. L. White, coauthor, Chemical Science and Technology

$7 / 3 / / 06$

ก

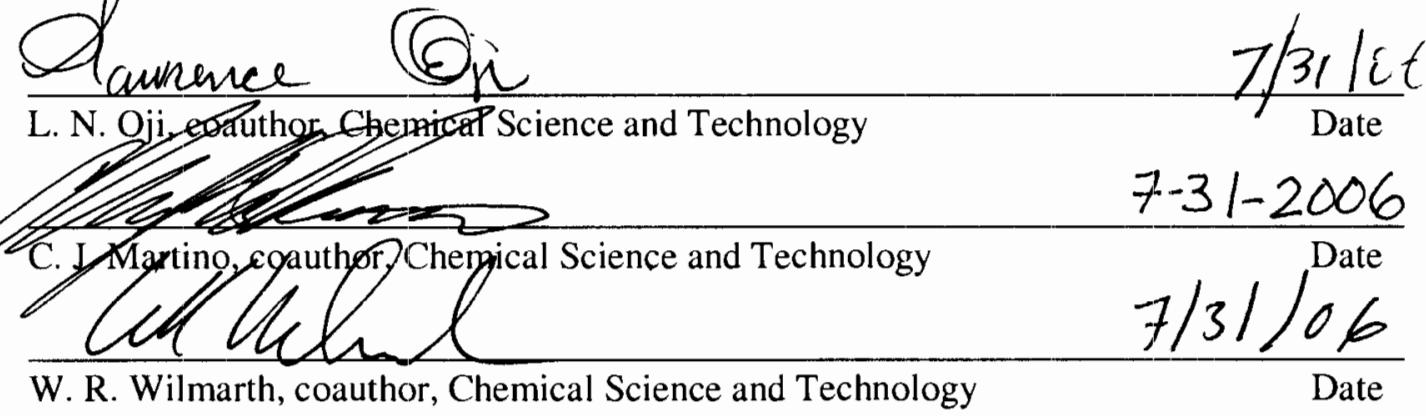

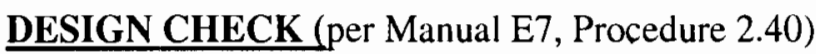

\begin{tabular}{lr} 
& $7 / 3 i / 06$ \\
\hline W. D. King, Chemical Science and Technology & Date
\end{tabular}

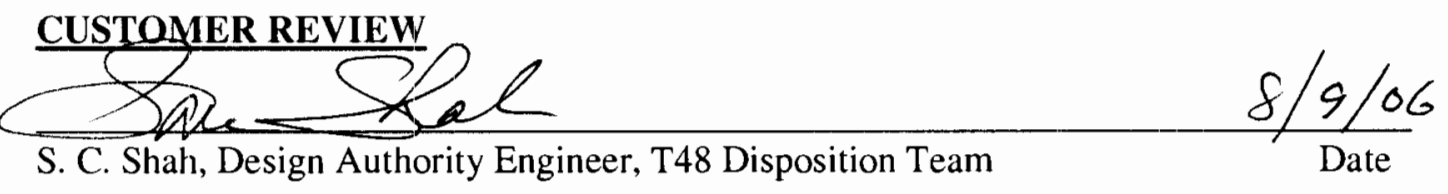

\section{APPROVALS}

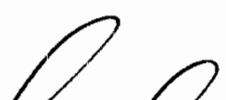

$\bar{W}$. R. Wilmarth, Manager, Chemical Science and Technology

$7 / 31 / 06$

Date

J. C. GRffin, Manager, Crkerfical Science and Technology
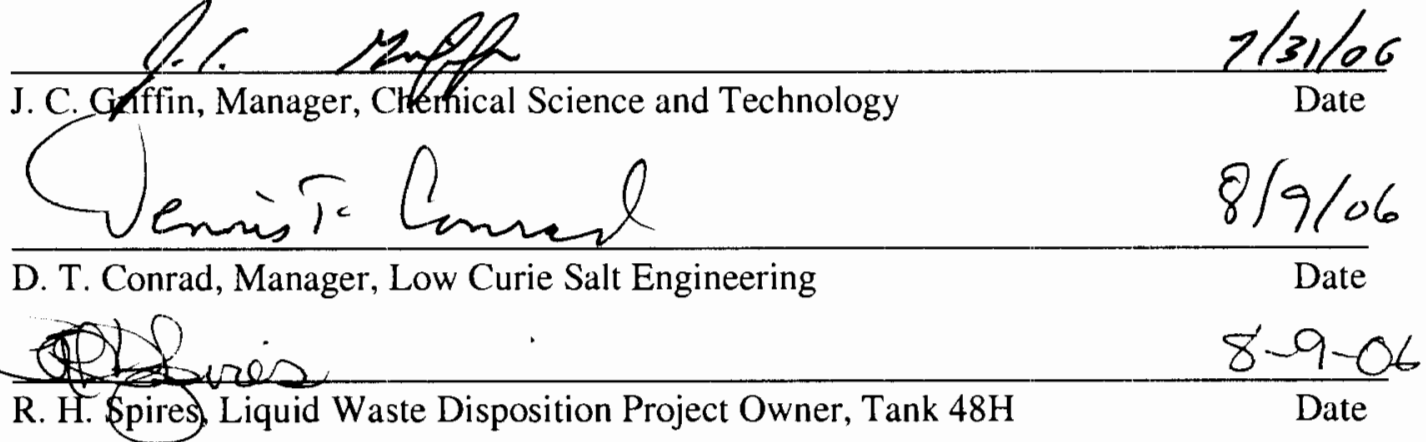


\section{TABLE OF CONTENTS}

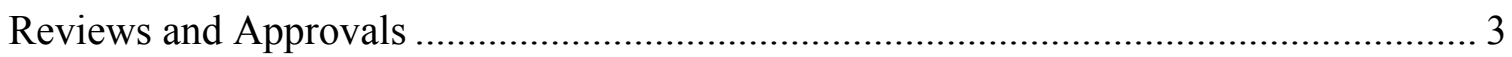

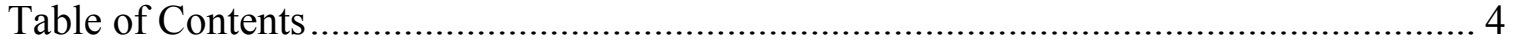

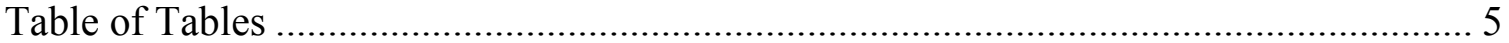

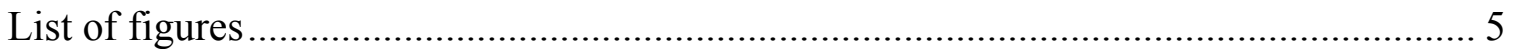

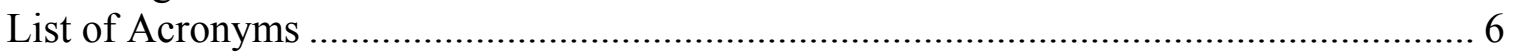

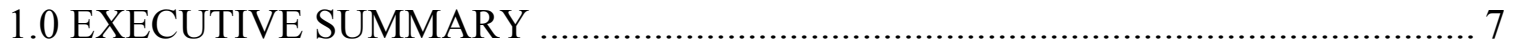

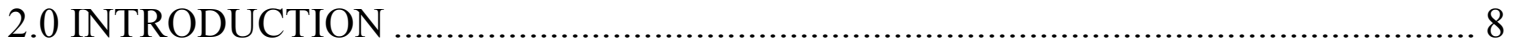

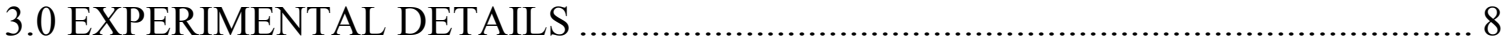

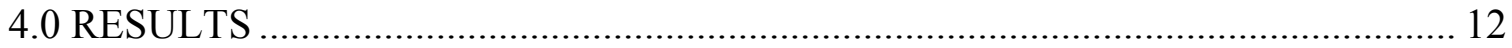

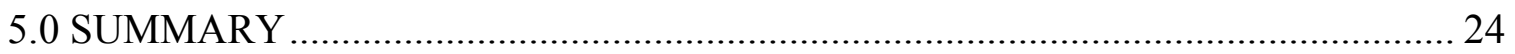

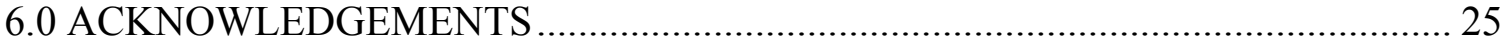

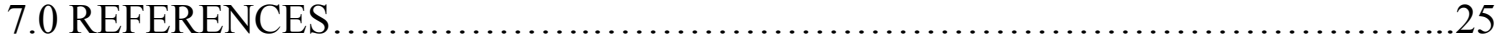




\section{TABLE OF TABLES}

Table 1 - Composition of the the Tank $23 \mathrm{H}$ simulant s........................................................... 10

Table 2- The Gravimetric Characteristics of the Pipes Determined by the ASTM D 3483-05......13

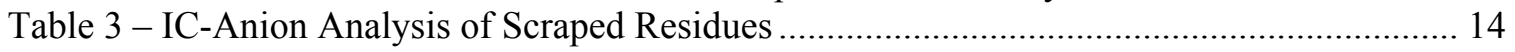

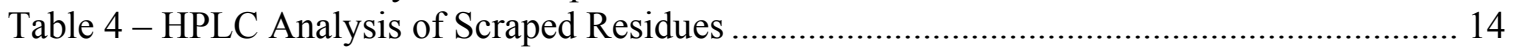

Table 4A. Residue vs. Dry Slurry Solids - Composition Comparison (wt \%) ................... 14

Table 5 - Actinide Estimation of Scraped Residues.................................... 15

Table 6 - TPB analysis of Leached Pipes.............................................. 17

\section{LIST OF FIGURES}

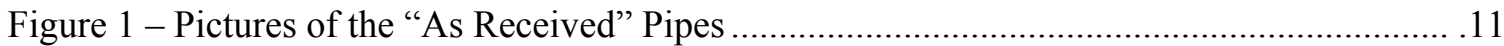

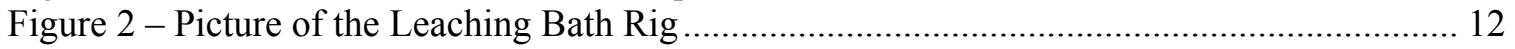

Figure 3 - Soluble TPB concentration as a function of time Inhibited water................. 18

Figure 4 - Soluble TPB concentration as a function of time Tank $23 \mathrm{H}$ simulant................19

Figure 5- "Shrinking Core" model fitting of the soluble TPB data from IW and T23H

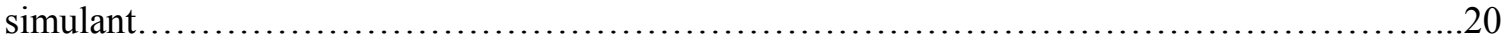

Figure 6 - Insoluble TPB concentration as a function of time..................................

Figure 7 - A picture of Pipe \# 1 Before and After Soaking in Inhibited Water....................22

Figure 8 - A picture of Piper \# 2 Before and After Soaking in Tank 23H Simulant..............23 


\section{LIST OF ACRONYMS}

\begin{tabular}{|c|c|}
\hline $1 \mathrm{~PB}$ & phenylboronic acid \\
\hline $2 \mathrm{~PB}$ & diphenylborinic acid \\
\hline $3 \mathrm{~PB}$ & Triphenylborane \\
\hline $4 \mathrm{~PB}$ & tetraphenylborate anion $-\left[\mathrm{B}\left(\mathrm{C}_{6} \mathrm{H}_{5}\right)_{4}\right]^{-}$ \\
\hline ADS & Analytical Development Section \\
\hline ASTM & American Society for Testing and Materials \\
\hline CsTPB & Cesium tetraphenylborate $\left(\mathrm{Cs}\left[\mathrm{B}\left(\mathrm{C}_{6} \mathrm{H}_{5}\right)_{4}\right]\right)$ \\
\hline FW & formula weight \\
\hline HPLC & High Performance Liquid Chromatography \\
\hline $\mathrm{IC}$ & Ion Chromatography \\
\hline ICP-ES & Inductively Coupled Plasma - Emission Spectrometry \\
\hline ITP & In-Tank Precipitation \\
\hline КТРB & Potassium tetraphenylborate $-\mathrm{K}\left[\mathrm{B}\left(\mathrm{C}_{6} \mathrm{H}_{5}\right)\right]_{4}$ \\
\hline LOD & Limit of Detection \\
\hline MST & monosodium titanate \\
\hline MW & molecular weight \\
\hline NA & not applicable \\
\hline NM & not measured \\
\hline NaTPB & sodium tetraphenylborate $-\mathrm{Na}\left[\mathrm{B}\left(\mathrm{C}_{6} \mathrm{H}_{5}\right)_{4}\right]$ \\
\hline SRNL & Savannah River National Laboratory \\
\hline ТPB & tetraphenylborate $-\left[\mathrm{B}\left(\mathrm{C}_{6} \mathrm{H}_{5}\right)_{4}\right]^{-}$ \\
\hline $95 \%$ confidence level & 95 out 100 chances the mean value will lie in this interval \\
\hline Std Dev & The length of the measuring interval or precision \\
\hline
\end{tabular}




\subsection{EXECUTIVE SUMMARY}

Solid residues on two sets of thermowell pipe samples from the D2 riser in SRS Tank $48 \mathrm{H}$ were characterized. The residue thickness was determined using the ASTM standard D 3483-05 and was found to be three order of magnitudes below the $1 \mathrm{~mm}$ thickness estimated from an earlier video of the tank cooling coil inspection. The actual estimated thickness ranged from 4 to 20.4 microns. The mass per unit area ranged from 1 to 5.3 milligrams per square inch. The residues appear to consist primarily of potassium tetraphenylborate (39.8 wt\% KTPB) and dried salt solution (33.5 $\mathrm{wt} \%$ total of nitrates, nitrites and oxalate salts), although $\sim 30 \%$ of the solid mass was not accounted for in the mass balance. No evidence of residue buildup was found inside the pipe, as expected. The residue leaching characteristics were measured by placing one pipe in inhibited water and one pipe in DWPF Recycle simulant. After soaking for less than 4 weeks, the inhibited water was $95.4 \%$ effective at removing the residue and the DWPF Recycle simulant was $93.5 \%$ effective. The surface appearance of the pipes after leaching tests appeared close to the clean shiny appearance of a new pipe. Total gamma counts of leachates averaged $48.1 \mathrm{dpm} / \mathrm{ml}$, or an equivalent of 2.35E-11 Ci/gm Cs-137 (dry solids basis), which is much lower than the $1.4 \mathrm{E}-03 \mathrm{Ci} / \mathrm{gm}$ expected for Tank 48 dry slurry solids. 


\subsection{INTRODUCTION}

A key component for the accelerated implementation and operation of the Salt Waste Processing Facility (SWPF) is the recovery of Tank $48 \mathrm{H}$. Tank $48 \mathrm{H}$ is a type IIIA tank with a maximum capacity of 1.3 million gallons. Video inspection of the tank showed that a film of solid material adhered to the tank internal walls and structures between 69" and 150 " levels. From the video inspection, the solid film thickness was estimated to be $1 \mathrm{~mm}$, which corresponds to $\sim 33 \mathrm{~kg}$ of TPB salts (as $20 \mathrm{wt} \%$ insoluble solids). ${ }^{1}$

This film material is expected to be easily removed by single-rinse, slurry pump operation during Tank 48H TPB disposition via aggregation processing. A similar success was achieved for Tank 49H TPB dispositioning, with slurry pumps operating almost continuously for approximately 6 months, after which time the tank was inspected and the film was found to be removed. The major components of the Tank $49 \mathrm{H}$ film were soluble solids $-\mathrm{Na}_{3} \mathrm{H}\left(\mathrm{CO}_{3}\right)_{2}$ (Hydrated Sodium Carbonate, aka: Trona), $\mathrm{Al}(\mathrm{OH})_{3}$ (Aluminum Hydroxide, aka: Gibbsite), NaTPB (Sodium Tetraphenylborate), $\mathrm{NaNO}_{3}$ (Sodium Nitrate) and $\mathrm{NaNO}_{2}$ (Sodium Nitrite). ${ }^{2}$ Although the Tank $48 \mathrm{H}$ film is expected to be primarily soluble solids, it may not behave the same as the Tank $49 \mathrm{H}$ film. There is a risk that material on the internal surfaces of Tank $48 \mathrm{H}$ could not be easily removed. As a risk mitigation activity, the chemical composition and leachability of the Tank $48 \mathrm{H}$ film are being evaluated prior to initiating tank aggregation.

This task investigated the dissolution characteristics of Tank 48H solid film deposits in inhibited water and DWPF recycle. To this end, SRNL received four separate 23-inch long thermowell-conductivity pipe samples which were removed from the tank 48H D2 risers in order to determine: 1) the thickness of the solid film deposit, 2) the chemical composition of the film deposits, and 3) the leaching behavior of the solid film deposit in inhibited water (IW) and in DWPF recycle simulant. ${ }^{3}$ This work has been authorized by the cited Technical Task Request and Technical Task Plan documents. ${ }^{4,5}$

\subsection{EXPERIMENTAL DETAILS}

The thermowell and conductivity probe samples removed from the Tank 48H D2 risers are composed of schedule 401 " stainless steel pipe (internal diameter equals 1.05 inches and outer diameter is 1.315 inches). Precautions were taken to minimize scratching of the pipes and removal of solid residue during handling. Inspection of the transport bags upon sample receipt indicated that little material had been lost from the pipes during transport. The four pipe sections had been cut from two separate tank $48 \mathrm{H}$ thermowellconductivity probes from the height range 70-124" above the tank bottom. This generated duplicate pipe samples for the tank height ranges 100-124" (sample \#1 and \#2) and 76-100" (sample \#3 and \#4). The actual measured length of the pipe samples after receipt was approximately 23". Shielded cell (SC) personnel received and placed the pipe samples in the A-block section of the cells. Personnel took pictures of the four pipes. Figure 1 shows the pictures of the four pipes used in this study. Inspection of Figure 1 shows that some of the pipes were partially wrapped with duct tape (sections of 
up to 5 inches in length). The ends of the pipes were sealed with blue polymeric caps. No noticeable amount of residue was found in the plastic bag after removing the pipes from the plastic bag. Close inspection of the residues on the pipes revealed that the films were not continuous or connected with variable thickness and appearance. For example, the films on pipes 2-4 had an imposed "spiral" like morphology (an area with little residue that wrapped around the pipe).

Personnel removed the blue caps at the ends of the pipes and performed a quick inspection of the inside of the pipes. To their surprise, they discovered another pipe with an outside diameter of approximately $5 \mathrm{~mm}$. Personnel removed the inside pipe and inspected the inside of the thermowell pipe again using a flash light and found no visual evidence of residue build up (light reflection from the internals surfaces appeared very specular). Personnel ensured that the insides of the pipes were sealed during the leaching test by inserting a filled PVC rod into the pipes and capping both ends.

\section{Film Deposit Thickness Determination:}

To analyze the thickness and composition of the film deposits on the pipe, personnel considered immersing small portions of the pipes in acetonitrile (known to dissolve TPB and its decomposition products), followed by immersion in distilled-deionized water (dissolves soluble salt analysis), and then digestion in a mixture of $\mathrm{HNO}_{3}-\mathrm{HCl}-\mathrm{HF}$. This method was not approved, due to safety issues in the cells. Another method of analyzing residues on pipes is to manually scrape off the residues and weigh them in accordance with the recommendations from the ASTM D 3483-05..$^{6}$ The average film thickness can then be determined from the total mass, the assumed or measured density, and the calculated surface area of the pipe. This standard method was developed for the removal of solids deposited onto the inner and outer surfaces of steam generator tubes. The procedure dictates specific residue removal methods for various mass surface concentration ranges. The lowest surface concentration range considered in this method is $16 \mathrm{grams} / \mathrm{ft}^{2}$. Before the pipes arrived to $\mathrm{SRNL}$, the estimated deposit or residue thickness on the pipes was 1 millimeter with an estimated weight of $30 \mathrm{grams} / \mathrm{ft}^{2}$, which corresponds to 0.1 grams of solids per inch. ${ }^{1}$ Based on this preliminary information, these samples were thought to be suitable for analysis using the ASTM method.

Residues were scraped from 5-inch portions of each pipe (1-4). Each of the collected residues was sent to the Analytical Development Section (ADS) for analysis. The ADS analyses included High Performance Liquid Chromatography (HP-LC) (for TPB and its decomposition products), IC-Anions (for inorganic anions), and gamma spectroscopy (primarily ${ }^{137} \mathrm{Cs}$ ). 


\section{Film Leaching Analysis:}

For residue leach testing two cylindrical baths (made out of quartz) were prepared with an average internal diameter of $74.5 \mathrm{~mm}$ to hold the pipes and the leaching solution in a vertical configuration. A picture of the leaching baths is shown in Figure 2. The total liquid volume of the vessels with a pipe inserted in the bath was 2.44 liters. The outer surface of the pipes was about $480 \mathrm{~cm}^{2}$. Therefore, the average pipe surface to liquid volume ratio was $0.2 \mathrm{~cm}^{-1}$. Note that the length of the pipe containing residue for these tests was 18 inches rather than 23 inches since 5 inches of residue was scraped away from each pipe for residue thickness determination as described above. Solutions used for leaching were inhibited water $\left(0.01 \mathrm{M} \mathrm{NaNO}_{2}\right.$ and $\left.0.01 \mathrm{M} \mathrm{NaOH}\right)$ and Tank $23 \mathrm{H}$ simulant (see Table 1). ${ }^{7}$ Pipe \#1 was leached with inhibited water and pipe \#2 was leached with Tank $23 \mathrm{H}$ simulant. Leach tests were not conducted with pipes 3-4. The leachate solutions were sampled periodically by collecting solution from the valves located at the bottom of the vessels. After each sampling event fresh solution was added to the vessel to raise the solution level to original height. The typical sampling volume was 0.06 liters. The liquid samples were filtered through 0.1 micron nylon filter paper, leached with acetonitrile, and analyzed by HPLC. The amount of TPB obtained from the filter paper was considered as insoluble TPB. The filtrate solution was also submitted to ADS for extraction with acetonitrile followed by HPLC analysis.

Table 1. Composition of the

Tank $23 \mathrm{H}$ simulant (Ref. 7)

\begin{tabular}{|c|c|}
\hline Component & Conc. [M] \\
\hline $\mathrm{NaOH}$ & 0.184 \\
\hline $\mathrm{NaNO} 2$ & 0.196 \\
\hline $\mathrm{NaNO} 3$ & 0.039 \\
\hline $\mathrm{Na} 2 \mathrm{CO} 3$ & 0.045 \\
\hline $\mathrm{Na} 2 \mathrm{SO} 4$ & $9.64 \mathrm{E}-04$ \\
\hline $\mathrm{NaF}$ & $1.05 \mathrm{E}-04$ \\
\hline $\mathrm{NaCl}$ & $1.14 \mathrm{E}-04$ \\
\hline $\mathrm{C} 2 \mathrm{O} 4$ & $1.25 \mathrm{E}-04$ \\
\hline
\end{tabular}




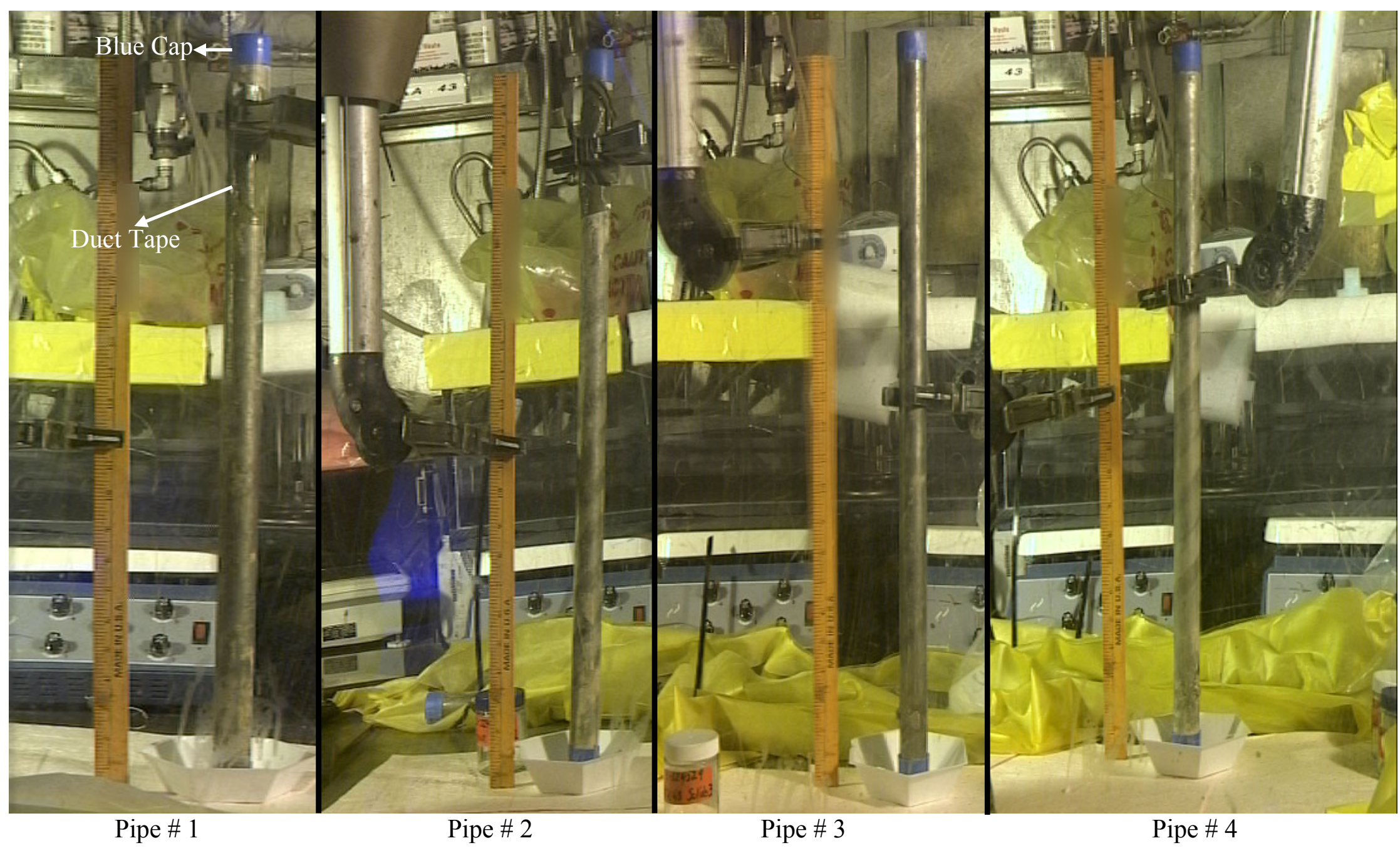

Figure 1. A picture of the 4 pieces of pipes from the D2 riser in Tank 48H that SRNL received in October 2005. Note some of the pipes arrive with duct tape attached on one end and the ends were covered with polymeric blue caps 


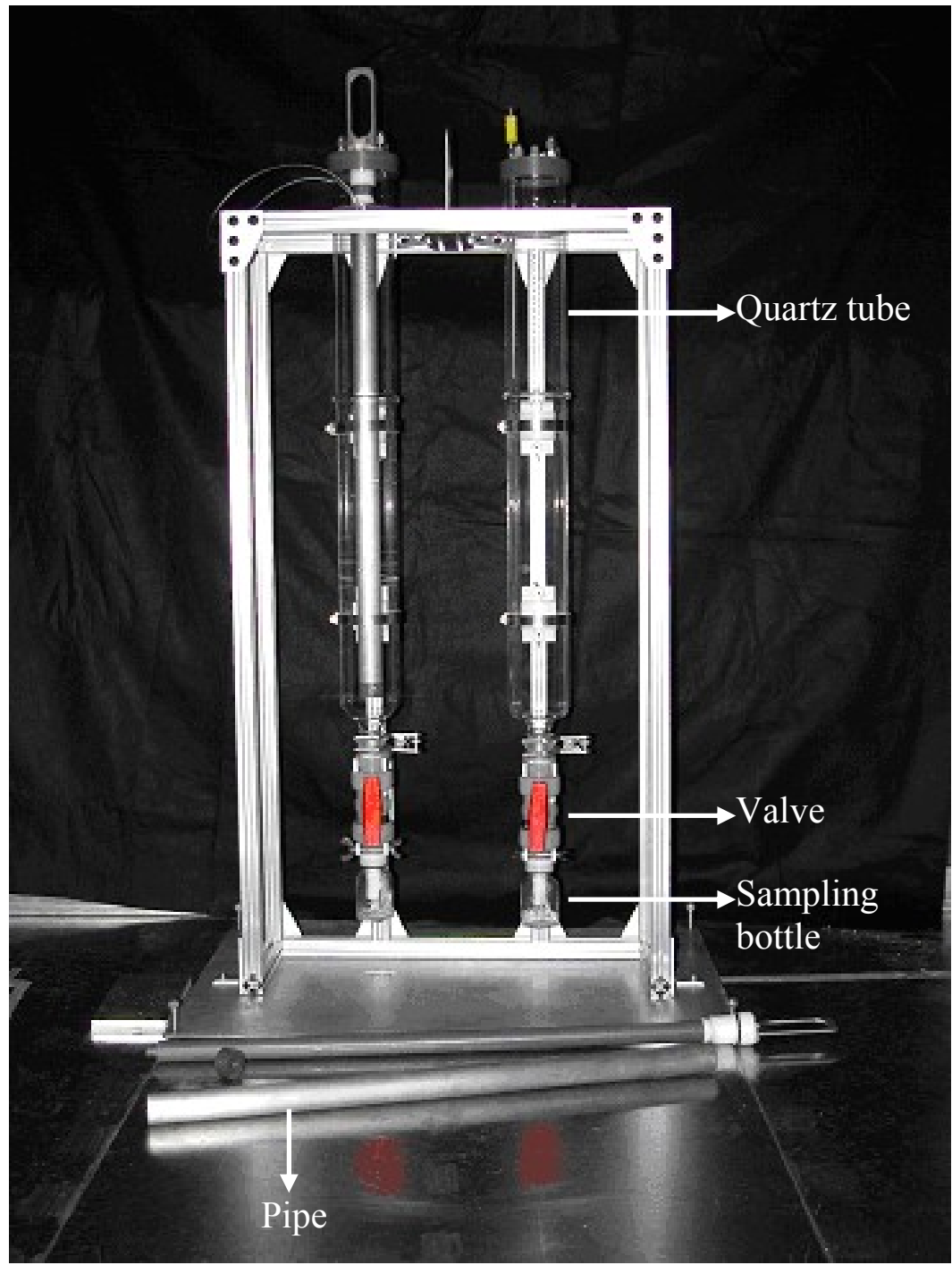

Figure 2. A picture of the two leaching baths used for placing pipes in the solutions.

\subsection{RESULTS}

Gravimetric Results for the Residue

Solid residues were manually scraped from five-inch sections of each pipe, which corresponds to an area of 20.7 square inches. The gravimetric results from this effort are provided in Table 2. Based on the data in Table 2, the amount of solids ranged from 1 to $3 \mathrm{mg} / \mathrm{in}^{2}$, depending on the pipe. These values are well below the lower limit of applicability for the ASTM D 3483-05 method of $111 \mathrm{mg} / \mathrm{in}^{2}$. Nonetheless, the calculated residue thickness is provided in Table 2 for each pipe assuming a solid density of 0.38 $\mathrm{g} / \mathrm{ml}$ (a quantity previously determined under controlled conditions ${ }^{8}$ ). The measured film thickness is three orders of magnitudes below the value $(1 \mathrm{~mm})$ estimated from the tank coil video inspection. One explanation for this discrepancy could be that the high 
intensity light or the distance and angle of the camera from the film during the video inspection may have resulted in a greater apparent film thickness. The film appeared thinner than $1 \mathrm{~mm}$ during visual inspection of the pipe samples at a close distance.

\section{Composition of the Residue}

The scraped residue from all four pipes was submitted for analysis by three different methods (HPLC, IC-Anions and ICP-AES) and the measured anion concentrations are provided in Table 3. The solid contains significant amounts of nitrate $\left(\mathrm{NO}_{3}{ }^{-}\right)$, nitrite $\left(\mathrm{NO}_{2}{ }^{-}\right)$, and oxalate $\left(\mathrm{C}_{2} \mathrm{O}_{4}{ }^{-}\right)$ions. The total amount of anions as estimated from Table 3 is $21.3 \mathrm{wt} \%$, which corresponds to $33.5 \mathrm{wt} \%$, if it is assumed that these are sodium salts. For comparison, Table 3 also includes similar analysis results for Tank 48 dried slurry solids published previously, in which the contribution of these anions as sodium salts was determined to be $25.3 \mathrm{wt} \%{ }^{9}$ The film residue and the dried slurry solids were similar in soluble salt composition. Measured TPB analysis results for these two sample types are provided in Table 4. The tetraphenylborate level measured in the thermowell residue was $35.4 \mathrm{wt} \%$ on a dry basis (33 $\mathrm{wt} \%$ on a wet basis). Assuming the TPB is present as the potassium salt, this value corresponds to be $39.8 \mathrm{wt} \% \mathrm{KTPB}$ on a dry basis ( $37 \mathrm{wt} \%$ on a wet basis). Since the estimated error in the HPLC method is $\pm 20 \%$, the KTPB concentration ranges from 31.8 to $47.8 \mathrm{wt} \%$. Mass balance summaries for the two sample types (thermowell residue and dried slurry solids) are provided in Table 4A. The analysis data for the thermowell residue accounted for $73 \mathrm{wt} \%$ (dry basis). Presumably, the remaining $26.7 \mathrm{wt} \%$ of the sample mass can be attributed to other unanalyzed salt components such as carbonates (not measured), hydroxyls (not measured), sludge, MST, and their hydrations of water.

Table 2. The Gravimetric Characteristics of the Pipes Determined by the ASTM D 3483-05

\begin{tabular}{|c|c|c|c|}
\hline Pipe \# & $\begin{array}{l}\text { Area Removed } \\
\text { from } 5 \text { inch } \\
\text { section }\left(\text { Inch }^{2}\right)\end{array}$ & $\begin{array}{l}\text { Mass Collected } \\
\text { from } 5 \text { inches of } \\
\text { pipe }(\mathrm{mg})\end{array}$ & Thickness $(\mathrm{mm})^{*}$ \\
\hline 1 & 20.7 & $20 \pm 4$ & $0.004 \pm 0.001^{\#}$ \\
\hline 2 & 20.7 & $40 \pm 8$ & $0.008 \pm 0.003$ \# \\
\hline 3 & 20.7 & $40 \pm 8$ & $0.008 \pm 0.003$ \# \\
\hline 4 & 20.7 & $70 \pm 15$ & $0.014 \pm 0.005^{\#}$ \\
\hline \multicolumn{4}{|c|}{$\begin{array}{l}\text { *This calculation assumes a density of } 0.38 \mathrm{~g} / \mathrm{ml} \text {. D. D. Walker, } \\
\text { "Combustibility of Tetraphenylborate," WSRC-RP- } 89-261 \text {, May } \\
1989 \text {. The density of salt crystals is somewhat higher for sodium } \\
\text { nitrate is around } 2.26 \mathrm{~g} / \mathrm{mL} \text {. Depending on porosity and salt fraction, } \\
\text { the density of the residue may be higher than } 0.38 \mathrm{~g} / \mathrm{mL} \text { For total } \\
\text { mass calculation, mass/area is a better parameter. }{ }^{\text {" Ranges were }} \\
\text { calculated per Ref. } 10 \text { methodology. }\end{array}$} \\
\hline
\end{tabular}


This combined amount of sludge and MST for the Tank 48 sample is large compared with the expected amount $3.6 \mathrm{wt} \%$ estimated from Ref. 9. This discrepancy may be due to an erroneous estimation of TPB concentration in the residue or the total mass collected during scraping in the hot cells. The balance used for these operations has an uncertainty of $10 \mathrm{mg}$. Alternatively, the discrepancy may be due to mass transfer loss from the scraping process during transfer to the analytical instruments in ADS. It is also possible that the steel surface may have preferentially sorbed MST and sludge.

Table 3. Anion Concentrations (wt \%) for the Thermowell Residue and the Tank 48 Slurry

\begin{tabular}{|c|c|c|c|c|c|c|c|c|c|}
\hline & $\begin{array}{l}\text { Formate } \\
\mathrm{HCOO}^{-}\end{array}$ & $\begin{array}{l}\text { Oxalate } \\
(\mathrm{COO})_{2}{ }^{2-}\end{array}$ & $\begin{array}{l}\text { Nitrite } \\
\mathrm{NO}^{-}\end{array}$ & $\begin{array}{l}\text { Nitrate } \\
\text { NO3 }^{-}\end{array}$ & $\begin{array}{c}\text { Phosphate } \\
\text { PO4 }^{-}\end{array}$ & $\begin{array}{l}\text { Sulfate } \\
\mathrm{SO}^{-}\end{array}$ & $\begin{array}{c}\text { Total } \\
\text { as } \\
\text { Na-salts }\end{array}$ & $\begin{array}{l}\text { Other } \\
\text { Salts }+ \\
\text { Misc }\end{array}$ & $\begin{array}{l}\text { Total } \\
\text { Salts }\end{array}$ \\
\hline $\begin{array}{c}\text { Thermowell Residue } \\
\text { (Dry Basis) }\end{array}$ & 1 & 4.8 & 8.4 & 6.5 & 0.05 & 0.4 & 33.5 & NM & NM \\
\hline $\begin{array}{l}\text { T48 Dried Slurry } \\
\text { Solids } \\
\text { "HTF-E-05-021" } \\
\text { Ref. } 9\end{array}$ & 0.21 & 0.61 & 10.0 & 6.0 & 0.18 & 0.14 & 25.3 & 43.6 & 68.5 \\
\hline
\end{tabular}

Table 4. Phenyl Borate Composition (wt\%) of the Thermowell Residue and the Tank 48 Slurry

\begin{tabular}{|c|c|c|c|c||c|c|}
\hline & $\begin{array}{c}\text { 4PB } \\
\text { (TPB) }\end{array}$ & $\begin{array}{c}\text { TPB } \\
\text { as } \\
\text { KTPB }\end{array}$ & 3 PB & 2 PB & 1 PB & Phenol \\
\hline $\begin{array}{c}\text { Thermowell Residue } \\
\text { (Dry Basis) }\end{array}$ & 35.4 & 39.8 & 0.2 & LOD (0.05) & LOD (0.05) & 0.4 \\
\hline $\begin{array}{c}\text { T48 Dried Slurry } \\
\text { Solids } \\
\text { "HTF-E-05-021" } \\
\text { Ref. 9 }\end{array}$ & 8.9 & 10.1 & 0.03 & 0.06 & 0.06 & 0.33 \\
\hline
\end{tabular}

Table 4A. Composition Comparison (wt\%) of the Thermowell Residue and the Tank 48 Slurry

\begin{tabular}{|c|c|c|c|c|c|c|}
\hline & $\begin{array}{c}\text { KTPB } \\
\text { (Insoluble) }\end{array}$ & $\begin{array}{c}\text { MST } \\
\text { (Insoluble) }\end{array}$ & $\begin{array}{c}\text { Sludge }+ \\
\text { Other } \\
\text { (Insoluble) }\end{array}$ & $\begin{array}{c}\text { Na-Salts } \\
\text { From Table 3 } \\
\text { (in Filtrate) }\end{array}$ & $\begin{array}{c}\text { Other Salts } \\
\text { (in Filtrate) }\end{array}$ & Total \\
\hline \hline $\begin{array}{c}\text { Thermowell Residue } \\
\text { (Dry Basis) }\end{array}$ & 39.8 & $\mathrm{NM}$ & $\mathrm{NM}$ & 33.5 & $\mathrm{NM}$ & $73.3+$ \\
\hline \hline $\begin{array}{c}\text { T48 Dried Slurry } \\
\text { Solids } \\
\text { "HTF-E-05-021" } \\
\text { Ref. 9 }\end{array}$ & 10.1 & 0.7 & 4.2 & 25.3 & 43.6 & 84 \\
\hline
\end{tabular}

The amount of physically sorbed water for the residue sample from pipe \#2 obtained by heating the sample to $100^{\circ} \mathrm{C}$ was determined to be $8 \mathrm{wt} \%$. 


\section{Gamma Count of the Residue}

The gamma counting of the residue solids measured less than $48.1 \mathrm{dpm} /$ grams of wet solids. Assuming the gamma energy is from cesium, the activity of the solids is $2.17 \mathrm{E}$ $11 \mathrm{Ci} /$ grams of wet solids or $2.35 \mathrm{E}-11 \mathrm{Ci} /$ grams of dried solids. This concentration is low in comparison to the concentration of cesium tetraphenylborate in Tank 48H slurry which was determined to be $1.4 \mathrm{E}-3 \mathrm{Ci} /$ gram of dried slurry. ${ }^{9}$ This may be an indication that estimating the residue composition from the dried slurry may not be appropriate since the steel surface may dictate what components from the slurry sorbs on it. The discrepancy may also be due to mass loss during the scraping efforts.

\section{Approximate Technetium and Actinides Concentrations in the Residue}

No measurement of the actinide concentration of the residue solids was made since it was not considered of significance during pre-planning of this test. The measured actinide concentrations from the Tank 48 slurry should represent a conservative upper limit for the residues. If we use the actinide concentration from Ref. 9, then upper bound estimate of the actinide concentration in the Thermowell residue is shown in Table 5.

\section{Leaching Results}

The concentrations of soluble and insoluble TPB in the inhibited water leaching solution observed as a function of time are shown in Figure 3 for pipe \#1. Two graphs are provided in Figure 3 showing both the concentration of soluble TPB in solution and the total mass of TPB in solution as a function of time. Close inspection of the data shows that the TPB concentration initially rises to a maximum value near 200 hours and then decreases.

Table 5. Technetium and Actinide concentrations in Tank 48H dried slurry solids ${ }^{9}$ as determined from previous measurements. The concentrations are assumed to be an upper bound in the actinide concentrations of the residues on the thermowell pipes.

\begin{tabular}{|c|c|c|}
\hline Component & $\begin{array}{c}\text { Average } \\
\text { (grams /grams of dried } \\
\text { slurry solids) }\end{array}$ & $\begin{array}{c}\text { Std Dev. } \\
\text { (grams /grams of } \\
\text { dried slurry solids })\end{array}$ \\
\hline $99(\mathrm{Tc})$ & $5.23 \mathrm{E}-06$ & $3.40 \mathrm{E}-07$ \\
\hline $237(\mathrm{~Np})$ & $7.36 \mathrm{E}-07$ & $1.70 \mathrm{E}-07$ \\
\hline $239(\mathrm{Pu})$ & $<1.91 \mathrm{E}-07$ & $1.91 \mathrm{E}-07$ \\
\hline $233(\mathrm{U})$ & $<3.83 \mathrm{E}-07$ & $3.83 \mathrm{E}-07$ \\
\hline $234(\mathrm{U})$ & $1.14 \mathrm{E}-06$ & $5.10 \mathrm{E}-08$ \\
\hline $235(\mathrm{U})$ & $2.40 \mathrm{E}-06$ & $2.13 \mathrm{E}-07$ \\
\hline $236(\mathrm{U})$ & $5.31 \mathrm{E}-07$ & $2.55 \mathrm{E}-08$ \\
\hline $238(\mathrm{U})$ & $1.41 \mathrm{E}-05$ & $1.53 \mathrm{E}-06$ \\
\hline TOTAL $(\mathrm{U})$ & $1.90 \mathrm{E}-05$ & $1.53 \mathrm{E}-06$ \\
\hline
\end{tabular}


The decline in the TPB concentration is due to the fact that the residue is no longer leaching significant amounts of TPB into solution after 200 hours and the fact that the solution was diluted by the liquid added after each sampling. This effect of dilution, however, only partially explains the observed decreases in TPB concentrations of the later samples. The predicted solubility for TPB in inhibited water $(\sim 20.3 \mathrm{mg} / \mathrm{L})$ is also shown in the graph. ${ }^{11}$ The plot on the right of Figure 3 shows the calculated cumulative amount of soluble TPB in milligrams leached into in the inhibited water. To obtain this number, the amount of TPB released by the residue between sampling and dilutions was calculated. In addition, the calculations accounted for the effect of dilution on the measured values. The amount of soluble TPB added between sampling and dilution was calculated using the mass balance equation that follows.

$\mathrm{V}_{\text {bath volume }}\left[\mathrm{C}_{\mathrm{i}}\right]=\mathrm{V}_{\text {bath volume }}\left[\mathrm{C}_{\mathrm{i}, \mathrm{i}-1}\right]+\left(\mathrm{V}_{\text {bath volume }}-\mathrm{V}_{\text {sampling volume }}\right)\left[\mathrm{C}_{\mathrm{i}-1}\right]$

In Equation 1, the symbol $\left[\mathrm{C}_{\mathrm{i}}\right]$ stands for the concentration of soluble TPB at time "i". The symbol $\left[\mathrm{C}_{\mathrm{i}, \mathrm{i}-1}\right]$ is the concentration of soluble TPB that leached from the residue between the last bath sampling at time "i-1" and the sample taken at time "i". Using this equation, the amount of soluble TPB added between sampling was calculated from the data shown in the left most graph of Figure 3. The results of the calculation yielded the total amount of TPB leached as a function of time in inhibited water as shown in the graph to the right of Figure 3.

The TPB concentration and the cumulative TPB leached into Tank $23 \mathrm{H}$ simulant solution as a function of contact time with pipe \#2 is provided in Figure 4. Slower leach rates were observed in this case. As was observed with pipe \#1 and inhibited water, TPB concentrations were observed which exceeded the calculated solubility limits in Tank $23 \mathrm{H}$ simulant. ${ }^{11}$

We fitted the shrinking core model for a dissolving cylinder to the data shown in Figures 3 and 4 . The shrinking core model is shown in equation $2 .^{12}$

$\mathrm{CFL}+(1-\mathrm{CFL}) * \mathrm{Ln}(1-\mathrm{CFL})=\mathrm{K}_{\text {diff }} *$ time, where $\mathrm{K}_{\text {diff }}$ is given by

$\mathrm{K}_{\text {diff }}=\mathrm{r}^{2} *$ Mass of TPB on Cylinder/(4D diffusion $*$ Porosity*Solubility)

Where " $\mathrm{r}$ " is the initial radius of the pipe + residue, CFL is the cumulative fraction leached, and $\mathrm{D}_{\text {diffusion }}$ is the diffusion coefficient for TPB diffusing through the residue with a given porosity. Figure 5 shows the data presented in Figures 3 and 4 except the format of the plots are different. The $\mathrm{Y}$-axis is shown representing time and the $\mathrm{X}$-axis represents the fraction of TPB leached with time. The graph on the left represents the fraction of TPB leached with time in the inhibited water simulant. In this graph there is a continuous line representing equation 2 . As can be seen the shrinking core model did not fit the data well. The graph on the right is the graphical representation of the data from the Tank $23 \mathrm{H}$ simulant. The line represents the best fit from the shrinking core model. The fit is better in this case and the value of the coefficient (" $\mathrm{K}_{\text {diff") }}$ ) is larger than the 
constant determined for the inhibited water. This is an indication of a larger amount of TPB on pipe \# 2.

Figure 6 shows the amount of insoluble TPB isolated from the filter paper used to filter the leachate samples as a function of contact time with the pipes. The graph on the left shows the amount of insoluble TPB in the inhibited water leachate with pipe \#1 reached a maximum at 200 hours and then decreased to below the detection limit. Similar behavior was observed with the Tank $23 \mathrm{H}$ simulant samples. This behavior indicates that the insoluble TPB was residing at the outermost layer of the residue on the pipes.

Table 6 summarizes the distribution of TPB mass in the leaching tests. The total mass of TPB remaining on pipe \#1 and \#2 was 4 and $9 \mathrm{mg}$, respectively (determined by acetonitrile wash and HPLC analysis). Little residual TPB $(<0.2 \mathrm{~g})$ was detected on the inside walls of the leaching baths or valves, indicating that the insoluble or soluble TPB did not stick to the walls of the baths. The total mass of TPB (both soluble and insoluble) obtained from pipe \#1 and \#2 in the leaching tests was 87.6 and $139 \mathrm{mg}$, respectively. This is more than the amount determined from the scraping effort. Also shown in Table 6 is the estimated thickness based on the TPB obtained from the leaching test. Considering all the sources of errors associated with collecting and handling powders, the total TPB mass obtained from the leaching test is selected as a more accurate number for determining the total residue mass. After four weeks of testing, the overall TPB leaching efficiency of the inhibited water and Tank $23 \mathrm{H}$ simulant was $95.4 \%(83.6 / 87.6)$ and 93.5 $\%$ (130/139), respectively.

Photographs of pipe \#1 and pipe \#2 before and after the leaching tests are provided in Figures 7 and 8, respectively. Based on the specular and diffuse reflectivity of the light from the pipes after contacting the leachate solutions, it appears that the pipes are clean with only trace amounts of TPB. HPLC analysis of the leached pipes \# 1 and 2 confirmed that only trace amounts of TPB remained on the pipes after the leach tests. Based on the data it appears that the dissolution of the soluble salts from the pipes leads to the release of the insoluble TPB solids. Although the pipes are made of stainless steel and the tank walls are made of carbon steel, this general conclusion involving salt dissolution is expected to apply to the tank walls as well.

Table 6. Distribution of TPB in leaching experiments with pipe \#1 and inhibited water and pipe \#2 with Tank 23H simulant

\begin{tabular}{|c|c|c|c|c|c|c|c|c|}
\hline $\begin{array}{c}\text { Pipe/Leaching } \\
\text { solution }\end{array}$ & $\begin{array}{c}\text { Amount } \\
\text { of } \\
\text { Insoluble } \\
(\mathrm{mg})\end{array}$ & $\begin{array}{c}\text { Amount } \\
\text { of } \\
\text { Soluble } \\
(\mathrm{mg})\end{array}$ & $\begin{array}{c}\text { Remaining } \\
\text { on the } \\
\text { pipes after } \\
\text { Leaching } \\
(\mathrm{mg})\end{array}$ & $\begin{array}{c}\text { Total } \\
\text { Mass } \\
\text { Leached } \\
(\mathrm{Col} \\
2+3) \\
(\mathrm{mg})\end{array}$ & $\begin{array}{c}\text { Total } \\
\text { Initial } \\
\text { Mass } \\
\text { (Col } \\
1+2+3) \\
(\mathrm{mg})\end{array}$ & $\begin{array}{c}\text { Percent } \\
\text { TPB } \\
\text { removed } \\
\text { from the } \\
\text { pipes after } \\
\text { 4 weeks }\end{array}$ & $\begin{array}{c}\text { Percent TPB } \\
\text { removed } \\
\text { from the } \\
\text { pipes after 1 } \\
\text { week }\end{array}$ & $\begin{array}{c}\text { Estimated } \\
\text { Thickness } \\
\text { from Col 6 } \\
\text { in mm) }\end{array}$ \\
\hline $\begin{array}{c}\text { Pipe \#1/ } \\
\text { Inhibited } \\
\text { Water }\end{array}$ & 2.19 & 81.44 & 4 & 83.6 & 87.6 & 95.4 & 95.2 & $0.013 \pm$ \\
\hline $\begin{array}{c}\text { Pipe \#2/ } \\
\text { Tank 23H } \\
\text { Simulant }\end{array}$ & 5.88 & 124.24 & 9 & 130 & 139 & 93.5 & 6.005 & $0.020 \pm$ \\
\hline
\end{tabular}



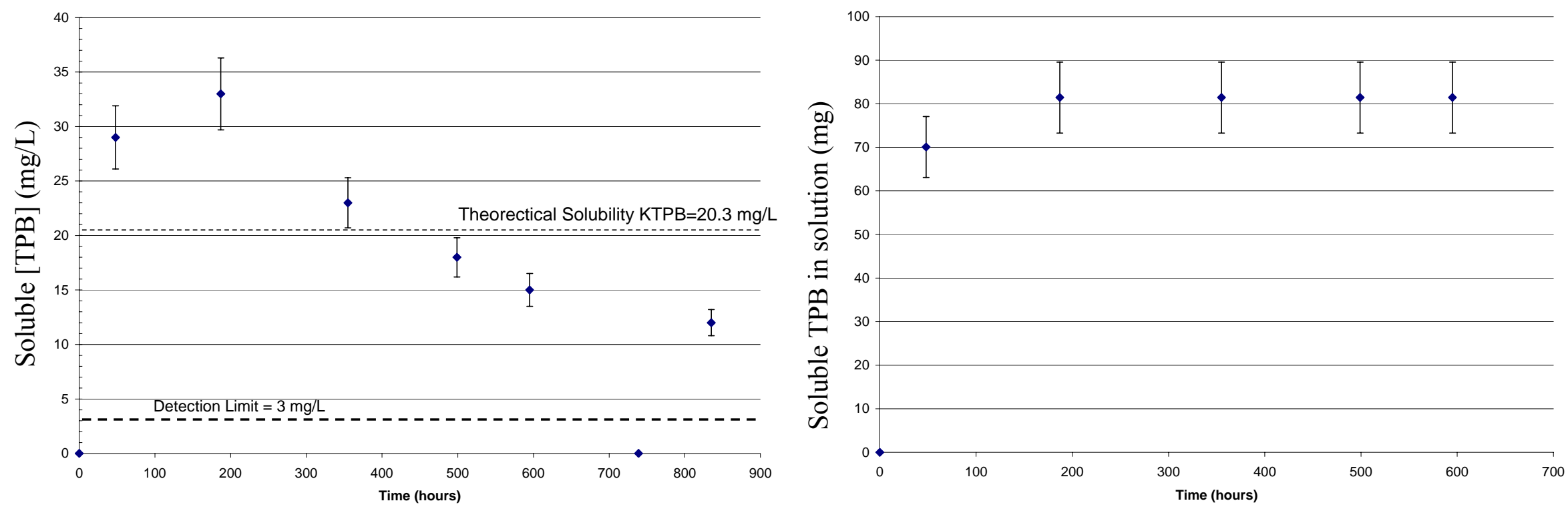

Figure 3. Left plot: Pipe \#1 actual soluble TPB concentration $(\mathrm{mg} / \mathrm{L})$ in inhibited water leachate as function of contact time. Right Plot: Cumulative mass of TPB leached from Pipe \#1 in inhibited water as a function time. 
WSRC-TR-2006-00135, REV.1

PAGE 19 OF 25
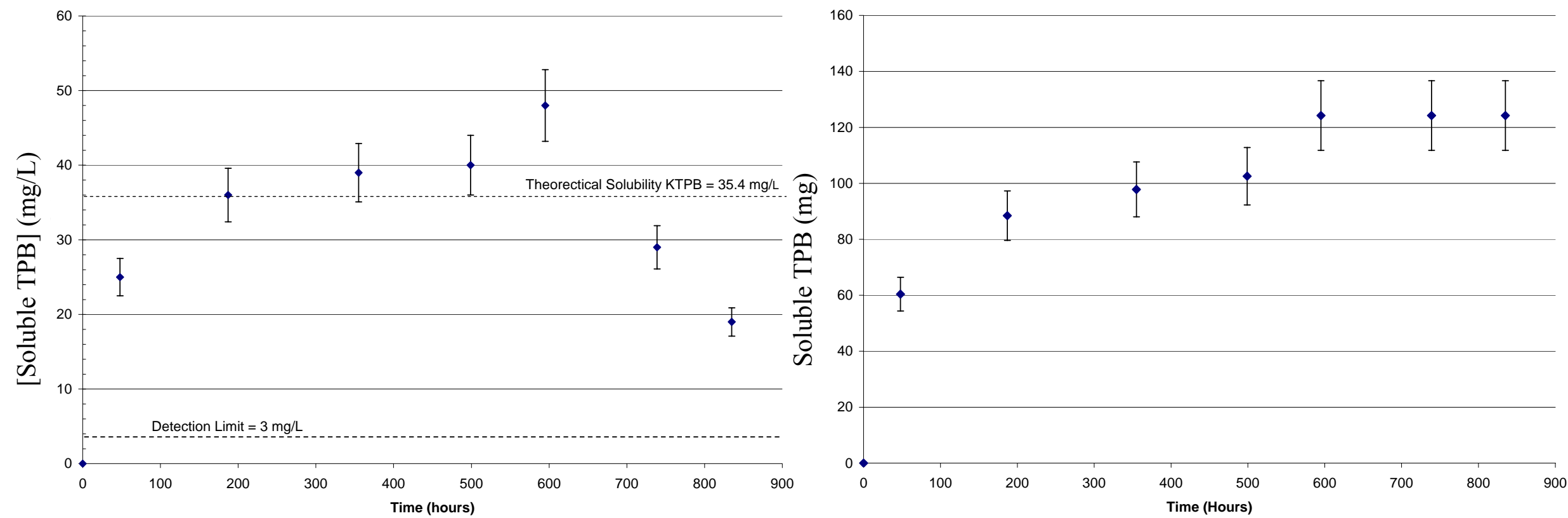

Figure 4. Left plot: Pipe \#2 actual soluble TPB concentration $(\mathrm{mg} / \mathrm{L})$ in Tank $23 \mathrm{H}$ stimulant leachate as function of contact time. Right Plot: Cumulative mass of TPB leached from Pipe \#2 in Tank $23 \mathrm{H}$ simulant as a function time. 

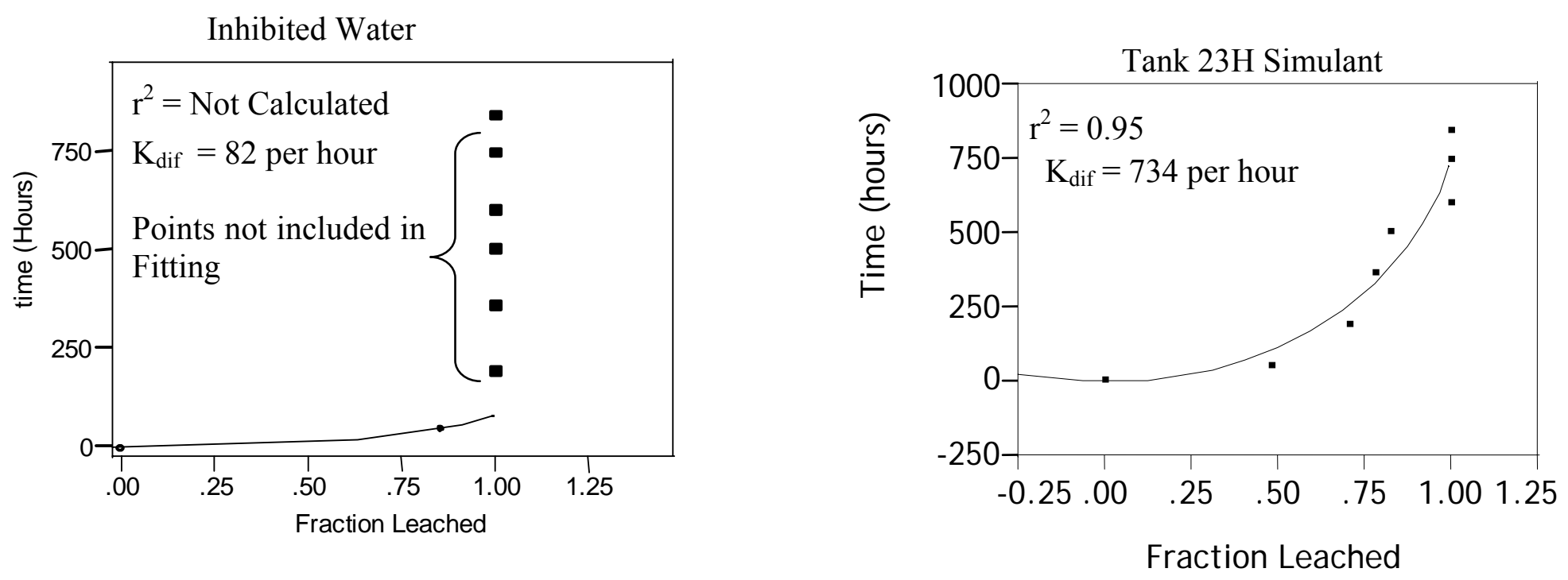

Figure 5. Left Plot: Fitting attempt based on the "Shrinking Core Model" for the TPB data collected for pipe\#1 immersed in inhibited water. Right Plot: Fitting attempt based on the "Shrinking Core Model" for the TPB data collected for pipe\#2 immersed in Tank 23H simulant. 

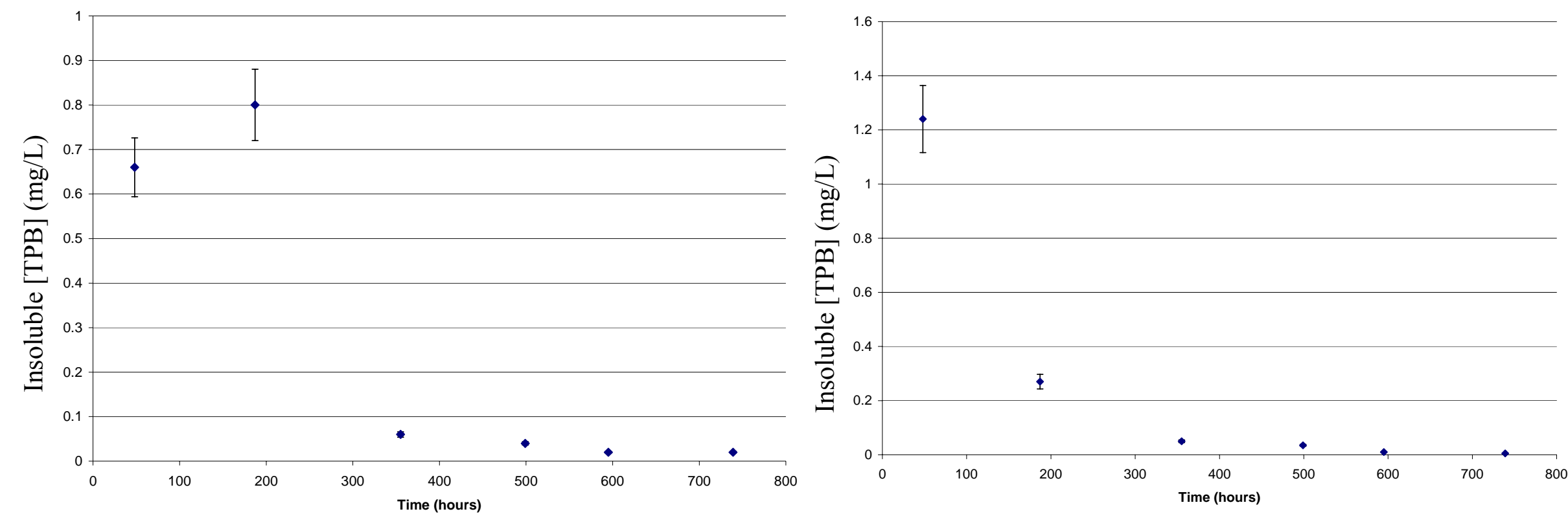

Figure 6. Left Plot: Measured TPB solids filtered from $0.06 \mathrm{~L}$ samples of inhibited water in contact with pipe \#1 as a function of time. Right Plot: Measured TPB solids filtered from $0.06 \mathrm{~L}$ samples of Tank $23 \mathrm{H}$ simulant in contact with pipe \#2 as a function of time. 


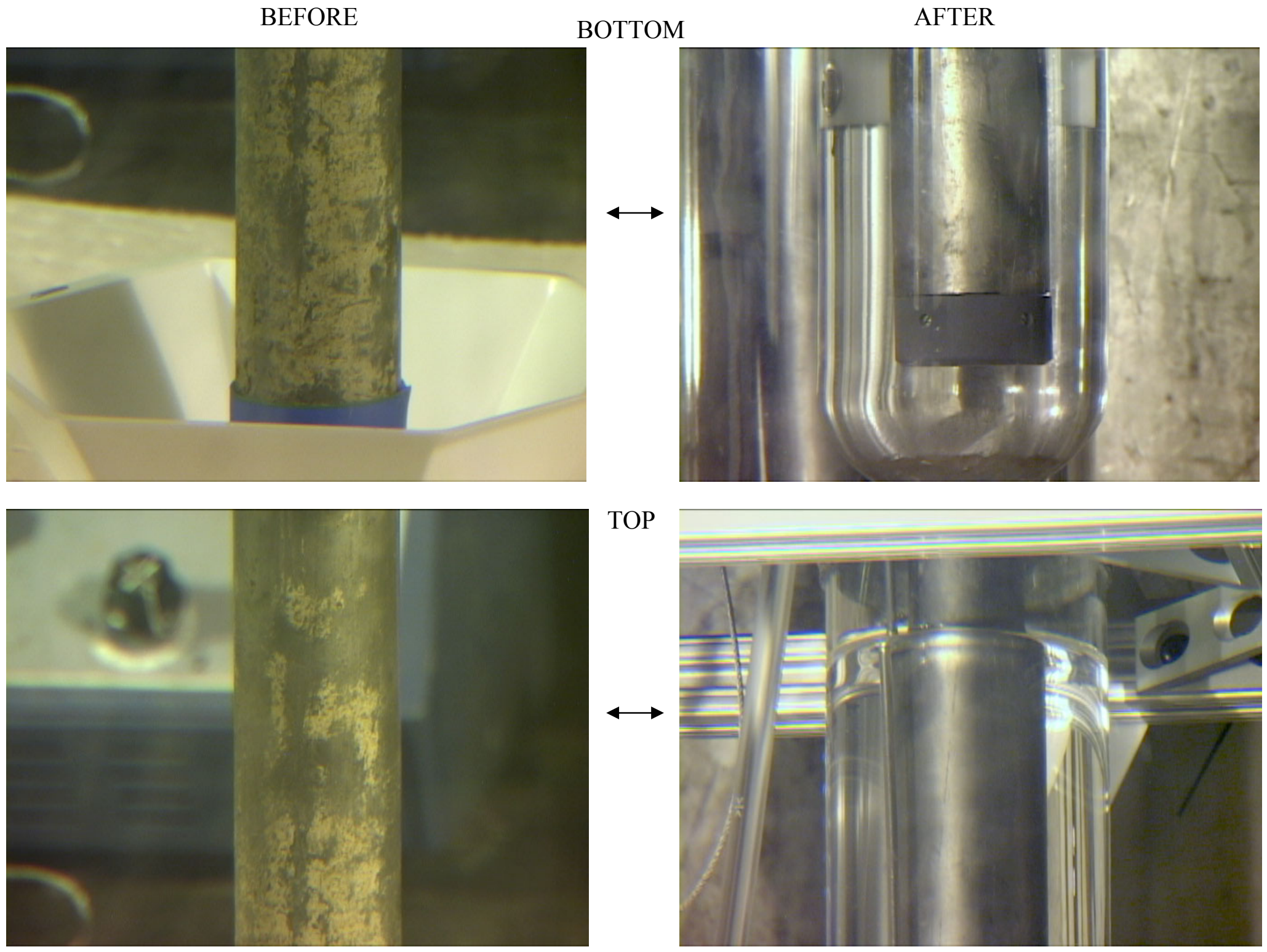

Figure 7. Photographs of pipe \#1 before (left) and after (right) 4-week contact with inhibited water.

Page 22 of 25 
WSRC-TR-2006-00135, REV.1

PAGE 23 OF 25

BEFORE

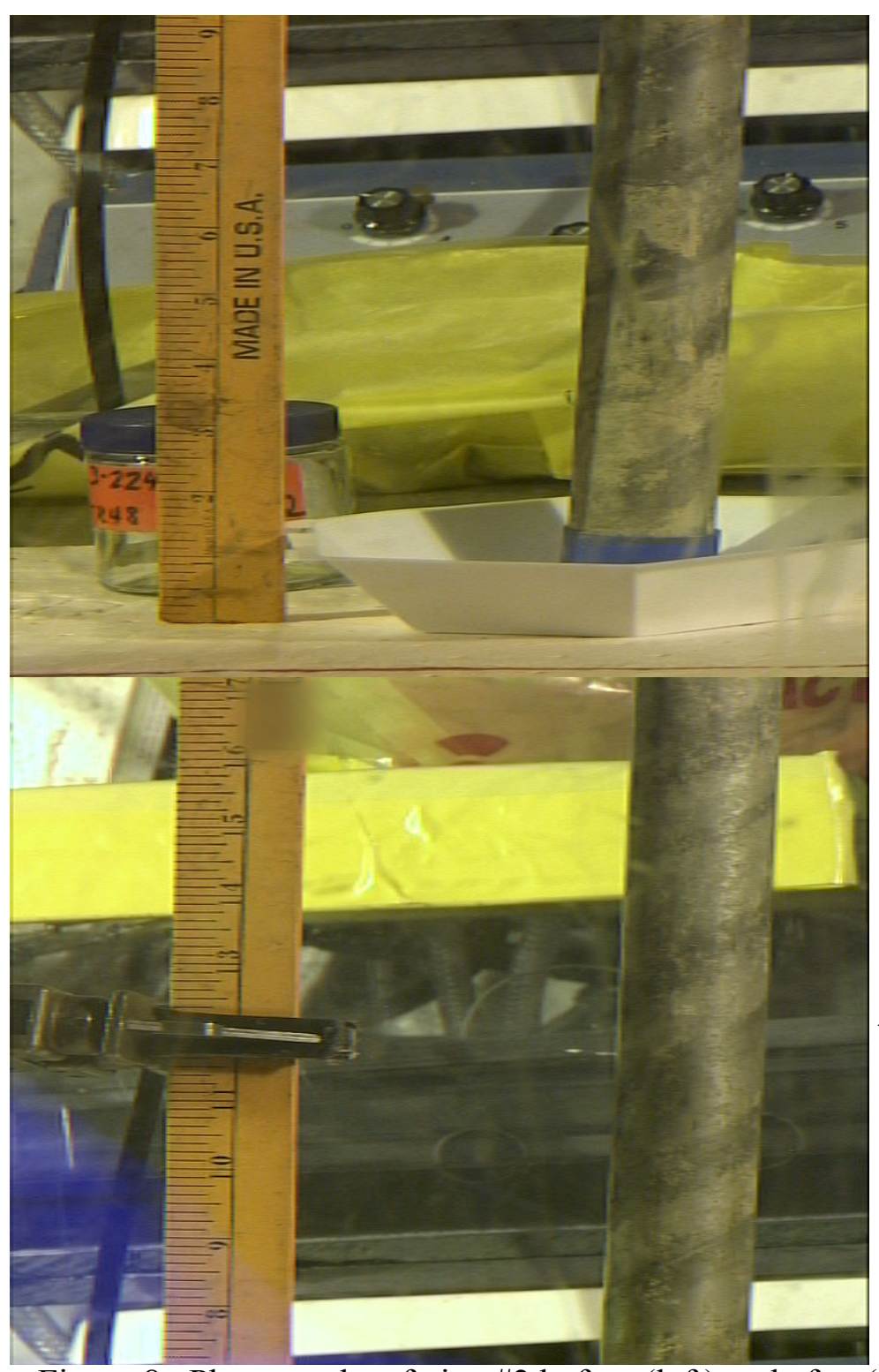

BOTTOM

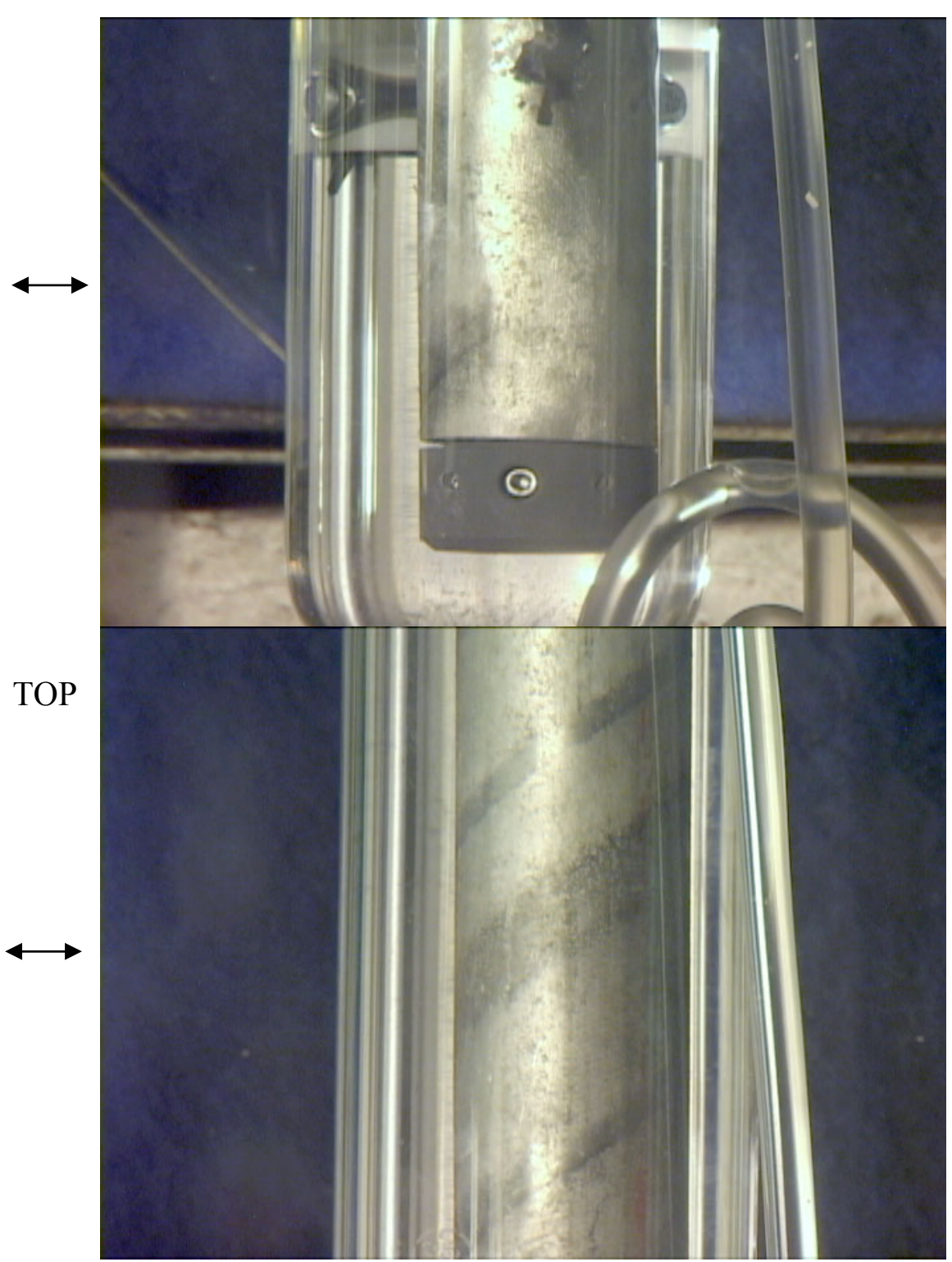

Figure 8. Photographs of pipe \#2 before (left) and after (right) 4-week contact with Tank $23 \mathrm{H}$ simulant.

Page 23 of 25 


\subsection{SUMMARY}

The residues on two sets of thermowell pipes samples from the D2 riser in Tank 48H were analyzed. The residue thickness was determined using the ASTM standard D 348305 and was found to be three order of magnitudes lower than the $1 \mathrm{~mm}$ thickness estimated from an earlier video of the tank cooling coils inspection. The high intensity light used for the video inspection may have caused the film to appear much whiter (giving a thicker appearance from absorption and re-radiating of the light waves), and performance of the video inspection from a distance and at an angle may have caused the film to appear thicker. The estimated thickness ranged from 4 to 20.4 microns.

The residues appear to consist mostly of potassium tetraphenylborate (39.8 wt $\%$ KTPB) and dried salt solution (33.5 wt $\%$ total of nitrates, nitrites and oxalate salts). No evidence of residue buildup was found inside the pipe. The residue leaching characteristics were measured by placing selected pipes in inhibited water and DWPF Recycle simulant. After soaking for less than 4 weeks, the inhibited water was $95.4 \%$ effective in removing KTPB residue and the DWPF Recycle simulant was 93.5\%. The surface appearance of the pipes after the leaching test appears close to that of a new pipe. The total gamma count of residues was measured to be $48.1 \mathrm{dpm} / \mathrm{ml}$ or an equivalent of $2.35 \mathrm{E}-11 \mathrm{Ci} / \mathrm{gm}$ Cs-137 (dry solids basis), which is much lower than $1.4 \mathrm{E}-03 \mathrm{Ci} / \mathrm{gm}$ expected from Tank 48 dry slurry solids. 


\subsection{ACKNOWLEDGEMENTS}

This task required the support of a large team of people. We thank the following individuals but note that many others assisted in completing this task.

We thank the dedicated Shielded Cells Technicians, especially Dee Wheeler and Monica Jenkins, for receiving the pipes, completing the analyses in the cells, and preparing the hundreds of samples for transfer to ADS.

We appreciate the support of the Tank 48H Disposition Team for their technical support in helping us accomplish this task.

\subsection{REFERENCES}

1 CBU-PIT-2005-00004, Rev 0, Volume and Content Estimate of Deposits on Tank 48H Internal Structures, W. B. Dean, January 12, 2005.

2 WSRC-TR-2000-00253, Rev 0, Tank 49 Disposition Plan, K. B. Martin, T. B. Peters, et al, July 20, 2000.

3 R. F. Calta, "Tank 48H Disposition: Residue Sample Retrieval and Analysis Plan," CBUSPT-2005-00145, September, 2005.

4 R. G. Calta, TTR entitled "Tank 48 Internal Residue Analysis", TTR-TK48-05-001 Rev. 0, July 5, 2005.

5 F. F. Fondeur, W. R. Wilmarth, "Task Technical And Quality Assurance Plan for the Characterization and Leaching of a Thermowell and a Conductivity Probe Pipe Sample From Tank 48H”, WSRC-TR-2005-00193, September 30, 2005.

6 ASTM D3483-05, "Standard Test Methods for Accumulated Deposition in a Steam Generator Tube."

7 L. N. Oji and M. S. Blume, "Characterization of Tank 23H Supernate Per Saltstone Waste Acceptance Criteria Analysis Requirements-2005," WSRC-TR-2005-00192, Rev. 0, May 2005.

8 D. D. Walker, “Combustibility of Tetraphenyl Borate,” WSRC-RP-89-261, May 1989.

9 F. F. Fondeur, D. P. Lambert, and S. D. Fink, "Analysis Of Tank 48H Sample HTF-E-05-021”, WSRC-TR-2005-00358, Rev.0, October 2005.

10 J. I. Seinfeld and W. L. Hays, "Chemical Kinetics," Prentice Hall, Cliffwood, NJ 1989, pp. $135-136$

11 D. J. McCabe, "Cesium, Potassium, and Sodium Tetraphenylborate Solubility in Salt Solution," WSRC-TR-96-0384, Rev. 0, December, 1996.

12 J. Y. Kim, C. L. Kim, C. H. Chung, "Leaching Characteristics of Paraffin waste Forms Generated from Korean Nuclear Power Plants,” Waste Management, 21, (2001), pp 325-333. 